\title{
UNDEMOCRATIC HISTORY POLITICS IN A DEMOCRATIC STATE: CELEBRATIONS OF FINLAND'S 100 YEARS OF INDEPENDENCE
}

\author{
JUHO KORHONEN \\ BOĞAZIÇI UNIVERSITY, ISTANBUL
}

\begin{abstract}
This article analyses the history politics of the Finnish state as illustrated by the organization of the celebrations of the centenary of Finland's independence. The article suggests that the Finnish state and its Finland 100 project promoted an undemocratic, controlled, and carefully curated approach towards the politics of history. An homage to pluralism was constructed on top of an immutable national narrative that was actively safeguarded and adopted as the only acceptable framework for interpretation of the connections between Finland's past, the present, and future. In other words, as the primary source documents I analyzed show, lip service to the "harmonious coexistence of different perspectives" was coupled with controls over contested and alternative interpretations, with guidelines that urged the Finland 100 organizers to "report any weak signals of crisis to central communications in good time."
\end{abstract}

Keywords: history politics; politics of history; Finland; democracy; nationalism; national anniversaries

DOI: $10.14712 / 23363231.2021 .9$

\section{Introduction}

In 2017 the Finnish state organized and coordinated massive celebrations of the centenary of its independence under the auspices of the Finland 100 project.

Juho Korhonen, Ph.D. is Assistant Professor of Sociology at Boğaziçi University, Istanbul. Address correspondence to Department of Sociology, Boğaziçi University, South Campus, 34342 Bebek, Istanbul, Turkey. E-mail: korhonen.sociology@gmail.com. 
In the end, the project organized about 170,000 events around the world. Its total budget was approximately 20 million euros. ${ }^{1}$ The celebrations were followed by extensive reporting that evaluated and promoted their results. There followed two years of research on what was termed by the organizers of the project as the "permanent legacy of the centenary." ${ }^{2}$ The government described the celebrations as a "historically exceptional phenomenon" that increased Finland's "social capital," "broadened [its] cultural diversity," established a "legacy," and carried "lessons for the next century of independence."3

In this article, I analyze the history politics (defined in detail below) behind the planning of the celebration and the subsequent reporting on its results. I analyze two aspects of the celebrations. First, I examine the historical interpretations and their connections to the present and future that were promoted by the organizers. I wanted to determine what connections they highlighted and what they left hidden and occluded. ${ }^{4}$ Second, building on what I learned, I analyze how Finland 100 presented these interpretations and connections, whether or not they were derived from historical research, how open and argumentative the process of arriving at them was, how amenable to debate and alternative perspectives the project was, and what relationship there was between historical research and the public sphere. My analysis will be contextualized and elaborated in a discussion of the questions and complexities of the Finnish politics of history, especially as regards how open and democratic is the relationship between on-going historical research and knowledge production with public and state promoted history. In a nutshell, I ask whether diverse voices of historians and of historical actors are equally heard in public and state promoted history. Drawing on this analysis, I characterize what kind of a history political actor the Finnish state is, as exemplified by the Finland 100 celebrations.

In my research, I analyzed material produced by and about the Finland 100 project. The main documents are a 152-page report published by the organizing committee and a hundred-page analysis of the Finland 100 project's results commissioned by the Office of the Prime Minister. The latter was produced by

1 Valtioneuvoston kanslia [The Prime Minister's Office] (hereafter VNK), Suomi 100 vuotta. Yhdessä. Suomi 100 -juhlavuoden raportti. Valtioneuvoston kanslian julkaisusarja 9/2018, 28-31, http:// urn.fi/URN:ISBN:978-952-287-664-5.

2 Ibid., 5, 83.

3 Ibid.

4 For the term "occlusion" see for example David Jenkins and Steven Lukes, "The power of occlusion," Journal of Political Power 10, no. 1 (2017): 6-24, doi: https://doi.org/10.1080/215837 9X.2017.1285156, or Julian Go, "Occluding the Global: Analytic Bifurcation, Causal Scientism, and Alternatives in Historical Sociology," Journal of Globalization Studies 5, no. 1 (2014): 122-136. 
a consortium of private research companies and a think tank. ${ }^{5}$ Other primary sources included materials produced during the organization of the festivities, such as promotional brochures and instructions and guidelines for participating companies, associations, and other entities. They also included press releases and notices issued by the Prime Minister's Office. Secondary materials included the few academic studies of the events produced so far, as well as general literature on the politics of history and history politics in Finland.

I argue that in the context of its history politics, Finland, otherwise a democratic country, maintains strict control over its national historical narrative. In fact, the need for a controlled consensus over an openly disputable historical narrative is asserted. Paradoxically, this is justified by a desire to maintain a democratic society and political system, both in the present day and in the future. In other words, a more democratic and research-based contestation of Finland's past is understood as a possible threat to the stability of the country's democracy. This belief creates a problematic gap between public debates and historical research to the effect that certain historical knowledge and perspectives are concertedly overlooked. All of this contributes to undemocratic history politics in Finland. Comparing Finland 100 and the idea of Finnish history it promoted to previous independence celebrations and to a variety of historical knowledge not recognized in public debates in general, I conclude that the Finland 100 celebrations exhibited a long-term logic of the Finnish mnemonic regime that shuns pluralistic and multisided interpretations of and discourse about the past.

Finnish historians Marja Jalava and Pauli Kettunen have made similar observations, pointing to a Finnish history politics that sees future progress as dependent on the active maintenance of an unchanged continuity between the present and past. ${ }^{6}$ Historical research that in other countries has led to the recognition of historical discontinuities, or politically different, alternative pasts, has in Finland led to an even narrower focus on continuities. Even as historical research has increasingly questioned this form of history politics, public political discourse backed by the state's authority through efforts such as independence celebrations continues to actively emphasize a one-sided historical interpretation. The

5 The 194491 Euro research has been conducted by Cupore, Owal Group Oy, and Demos Helsinki Oy. Suomi 100 -tutkimushanke, Statsrådets kansli - Valtioneuvoston kanslia, https://vnk.fi/suomi -100-tutkimushanke.

6 Marja Jalava and Pauli Kettunen, "Epilogi: jatkuvuudet, katkokset ja tulevaisuudet historiantutkimuksessa," in Menneet tulevaisuudet: Ajankohta, polittisen historian vuosikirja 2018, ed. Elina Hakoniemi, Iikka Kärrylä, Kristiina Silvan, and Riikka Taavetti (Helsinki: Helsingin yliopisto \& Turun yliopisto, 2018), 315-320. 
Finland 100 project presented a particular take on Finnish history with the intention of further monopolizing Finland's collective memory and mnemonic regime.

Within the wider international scholarship on collective memory and mnemonic regimes the Finnish case is somewhat particular. In the Finnish case, historical research, writing and interpretations as well as collective and public memory are not particularly politicized or publicly guarded activities, but the relationship between them is. The case is interesting in relation to recent trends in research literature. Geneviève Zubrzycki and Anna Woźny point to a trend in literature on collective memory and the politics of history that focuses on "the different processes through which collective memory and nationalism become imbricated in daily life."7 Peter Verovšek suggests that besides the formal institutions and substantive content of the politics of history, research should also focus on "the interactive channels through which ideas about the past are conveyed, disputed, silenced, and negotiated in society as a whole." In analyzing Finland 100, I follow Verovšek, as well as Zubrzycki and Woźny, in focusing on how those channels are managed and controlled - and thereby what kind of perspectives about how the past should be approached and understood are highlighted or occluded - and who as a result holds performative and symbolic power in the mnemonic regime. ${ }^{9}$ I will begin by outlining what I mean by history politics as a one dimension of democratic discourse, which is specifically related to the formation of collective memory and the processes that determine how the past is publicly discussed.

\section{History Politics and the Politics of History}

The politics of memory and the uses and abuses of history are wide fields of research, which posit that "remembering the past, particularly collectively, is always a political process." 10 This belief in the innately political nature of historical

7 Geneviève Zubrzycki and Anna Woźny, “The Comparative Politics of Collective Memory,” Annual Review of Sociology 46 (2020): 175-194, doi: https://doi.org/10.1146/annurev-soc-121919-054808.

8 Peter J. Verovšek, "Collective memory, politics, and the influence of the past: the politics of memory as a research paradigm," Politics, Groups, and Identities 4, no. 3 (2016): 537, doi: https: / doi.org /10.1080/21565503.2016.1167094.

9 Zubrzycki and Woźny, "The Comparative Politics of Collective Memory," 177.

${ }^{10}$ Michael Bernhard and Jan Kubik, Twenty Years after Communism: The Politics of Memory and Commemoration (Oxford and New York: Oxford University Press, 2014), 3, doi: 10.1093/acprof: oso/9780199375134.001.0001. 
knowledge and interpretations is paired with the idea that societal actors intentionally engage not only in promoting specific ideas about the past but, more importantly, in efforts to impact and even control the ways in which societies do and can discuss and debate the past. Bernhard and Kubik refer to such actors as "mnemonic actors," who are "political forces that are interested in a specific interpretation of the past. They often treat history instrumentally in order to construct a vision of the past that they assume will generate the most effective legitimation for their efforts to gain and hold power." 11 When successful, these actors can impose "mnemonic regimes," which constitute "the dominant pattern of memory politics that exists in a given society at a given moment in reference to a specific highly consequential past event or process," i.e. these "regimes constitute the building blocks of the official field of (collective or historical) memory." ${ }^{2}$ Much like a political regime, a mnemonic regime can be more or less open, and more or less democratic. It may seek to empower a variety citizens' and societal actors' capacities as mnemonic actors or, on the contrary, support certain exclusive hierarchies and limits on who gets to engage the past and use history, and how they can do so. As with political regimes, the state is usually the most powerful and capable mnemonic actor. The state can outsource interpretations of the past to select institutions, media outlets, or various civil society actors. Alternatively, it may seek to maintain strict control over such interpretations in its own hands or from time to time strategically intervene in their production and dissemination by others. The policies and practices of participation and recognition (inclusion and exclusion) of the state and of other actors with power over the past and the interpretations of history form a history politics.

At the extreme, some history politics may all but fully control, guide or suppress historical research, preventing any knowledge of the past and its connections to the present from becoming the subject of free inquiry and debate. Though never fully possible, in such extreme cases a society has no meaningful politics of history. An analogy with the existence of an autonomous civil sphere is quite apt; though never fully extinguishable, the political effects of an autonomous and capable civil sphere can be mostly suppressed. As with a similar distinction in democratization research, history politics then relates to the participatory and deliberative aspects in contrast to the politics of history, which relates to the institutional terrain. History politics is about the capacity to be heard, to make claims and to put forward historical interpretations. The politics of history is

11 Ibid, 4.

12 Ibid. 
about the infrastructure and institutions, the fora where historical knowledge is discussed. ${ }^{13}$ The Finland 100 celebrations were one highly visible and extensive forum of Finnish politics of history. In this article I focus on who and what kind of historical knowledge gained access to and visibility in that forum. In other words, I focus on history politics.

History politics actively define the limits and the constitution of the politics of history. In most countries, national histories are actively foregrounded in preference to other historical perspectives, and the connections and questions those other perspectives evoke. That is a history political act that can shape the uses of history, such as the hierarchies between different meanings of and perspectives on historical knowledge. For example, we may end up emphasizing domestic processes of nation-making over transnational ones and at the same time, with that very juxtaposition, also occlude from consideration the historical entanglements between those two perspectives. Especially in democratic societies, these type of issues should be open for debate as political questions. How much funding, for example, should be made available for historical research? What kind of historical research? Is that funding to be given to projects inside or outside academic institutions? Should the projects be about the nation or about something else? How much state support should there be for the publication of history-related books, both academic and non-fiction? And especially, how much support for promotion of an active, open and democratic politics of history is there in society, and what institutions and practices are in place to support it? The activities of those institutions connect historical research of various kinds with the public sphere. In an open, democratic environment they welcome alternative, minority, and critical perspectives. With this comes of course a caveat: support for one historical topic, question or perspective will always mean that another one goes unsupported in terms of both resources and visibility. This is another reason why decisions and policies regarding history are political.

At its simplest, then, the politics of history refers to how at any given time and place society lays the foundations and set the limits within which the past is

${ }^{13}$ For example, Hackmann makes a similar distinction between the politics of history as the general spaces of public debates about history and history politics or what he then terms history policies as the often symbolic or ideological battles over who represents acceptable historical knowledge. See Jörg Hackmann, "Defending the 'Good Name' of the Polish Nation: Politics of History as a Battlefield in Poland, 2015-18," Journal of Genocide Research 20, no. 4 (2018): 587-606, doi: https://doi.org/10.1080/14623528.2018.1528742. Verovšek makes a similar distinction between the substantive content and institutions, on the one hand, and interactive and discursive channels, on the other, where the politics of memory play out. See Verovšek, "Collective memory, politics, and the influence of the past." 
researched, interpreted, presented - and as a result, remembered. ${ }^{14}$ In a democratic society with a free and open public sphere, historical interpretations and presentations are open to debate, and subjected to freely conducted historical research. They are free of political constraints and pressure, or favoritism, when it comes to financing and symbolic gestures by the state. In other words, historical interpretations and activities are open to democratic exchange, struggle and contestation. I do not mean by this to promote any ideas of objective historical truths, or imaginaries of "the past as it actually happened." Rather, I recognize the fact that history is the "most ideological of sciences," as historian Ronald Grigor Suny, among others, has pointed out. ${ }^{15}$ It is the recognition of the latter, rather than the pursuit of the former, that highlights the importance of democratic history politics.

By maintaining and supporting open historical research and interpretations on the one hand, and on the other, the capacity of members of society to debate history's connection to the present and the future, a democratic society can deal with troubled pasts in an inclusive manner. This includes accepting interpretations and evidence as well as discussion even of past events and trajectories that are divisive, troublesome and that may bring into question basic assumptions, myths, and norms of national, social, and political identities. This often leads to tensions, not only between different segments of society, but also between historians' views and the collective memory - that is, what people assume others also believe and take for granted about their imagined national narrative.

To maintain and achieve a democratic politics of history, history politics is intentionally used or approached as a means to open and sustain inclusive and argumentative debate over historical interpretations. This type of history politics ideally aims at an increasingly self-reflexive understanding of its own boundaries and limitations. ${ }^{16}$ Perhaps the most common example of such an approach to history politics in academia is the various debates concerning problems of methodological nationalism and nationally bounded historiographies. Germany provides another famous example. There the term Vergangenheitsbewältigung refers to open and public debate about the Nazi period. Historian Seppo Hentilä

${ }^{14}$ See for example Kimmo Elo, “Satavuotias Suomi Katsoi Peiliin ja Menneisyyteensä,” Ennen ja Nyt, September 19, 2018, https://www.ennenjanyt.net/2018/09/satavuotias-suomi-katsoi-peiliin -ja-menneisyyteensa.

15 Ronald Grigor Suny, “Soviet Georgia in the Seventies," Washington, DC: Kennan Institute for Advanced Russian Studies, The Wilson Center (1979), 7, https://www.wilsoncenter.org/sites /default/files/media/documents/publication/op64_soviet_georgia_seventies_suny_1979.pdf.

16 This again is akin to how the participatory process relates to the institutions of democracy. 
clarifies that the idea is specifically not to control and get rid of troubled pasts, but to make even the most difficult histories open to discussion and approachable, so that they are researched as openly and widely as possible and subjected to the scrutiny of historical inquiry by historians and the public. ${ }^{17}$

We can say that a democratic history politics then aims to make the politics of history visible and known, including its possible limitations and shortcomings. This requires us to consider both the active as well as the passive interpretations and delineations of history that seek to hide, occlude or forget unwanted past events and processes (and in doing so highlight and even glorify others) for political and social purposes of the present. This type of "democratizing history" allows silenced actors to be heard, and overlooked or unwanted connections and conflicts to be examined, instead of imposing a consensus about what should be perceived as proper history, not to mention historical truths.

In summary, the politics of history refers to what could be characterized as a phenomenological concept, the constant presence and need for referring to the past that ultimately arises from and takes place in social and political structures and the interactions and discourse they enable or prevent. History politics refers to an intentional, agentic understanding. It refers to the instrumental use of history and the past in order to achieve certain societal or political goals. ${ }^{18}$ These goals may be more or less democratic. When analyzing the mnemonic regimes of a society, the relation between history politics and the politics of history needs to be considered.

Next, after a brief initial outline of the general characteristics of Finnish national history, I will discuss Finland's celebrations of the 100th anniversary of its independence as a case of history politics. I will examine its relation to the politics of history in Finland, and the democratic depth of this relation.

\section{Finland and the Politics of History}

The historian Pauli Kettunen has described the politics of history in Finland as fairly active and enthusiastic but centered around ideas of national necessities.

\footnotetext{
17 Seppo Hentilä, "Löytyykö totuus komissioista? Historiantutkimus ja totuuskomissiot," Tieteessä Tapahtuu 23, no. 8 (2005): 5-12, https://journal.fi/tt/article/view/57097.

18 Pilvi Torsti, "Historiapolitiikkaa tutkimaan: Historian poliittisen käytön typologian kehittelyä," Kasvatus ja Aika 2, no. 2 (2008): 61-71, https://journal.fi/kasvatusjaaika/article/view/68160.
} 
In the national past, "what was done, had to be done." 19 The traditional role of historians was "softening troubled pasts that prevented national integration." 20 Especially after the fall of the Soviet Union, the historian's role changed. Since then, national myths have been increasingly challenged by historical research that rejects the primacy and continuity of the national narrative. How this change in the relation of historical research and the public sphere will affect the relationship between history politics and the politics of history remains to be seen. This article hopes to contribute to an understanding of that relationship. Indeed, as historian Pertti Haapala notes, national history is not just the nation's collective memory; it is also its collective forgetfulness. ${ }^{21}$ In that sense, the dispelling of myths and a broader critique and discussion about a national past of necessities - or any transformations of the politics of the present and future will require an active engagement with Finland's national politics of history. We do not simply move away from past interpretations into new and "improved" ones. Historical interpretations do not advance on a linear trajectory of progress. Rather, historical interpretations and knowledge are connected to political ideas about the connections of the past, present and future.

Overall, the Finnish politics of history is centered around and supports a narrative of ever-increasing national unity and development. Several problematic events and turning points exist in Finnish history, but their political nature is largely dependent upon their relation to this central narrative. ${ }^{22}$ Some examples of historical processes that run counter to the idea of national sovereignty in Finnish history can clarify this distinction. One of them has been accepted into the central narrative, the others have not.

First, the term "Finlandization" still pops up today every now and then, usually pejoratively, as a political accusation. The term refers to the relation between Finland's foreign and domestic policy in the Cold War era. The American CIA described Finlandization in 1972 as "a highly developed sensitivity to Soviet wishes on a wide range of subjects and the ability and willingness to voluntarily restrict their [the Finns'] own courses of action." ${ }^{23}$ While still a highly politicized

19 Pauli Kettunen, “Kansallinen 'me' ja historia globaalistuvassa maailmassa," Tieteessä Tapahtuu 16, no. 5 (1998), 1-8, https://journal.fi/tt/article/view/58560.

20 Ibid.

${ }^{21}$ Pertti Haapala, “Tarvitaanko kansallista historiaa?” Tieteessä Tapahtuu 16, no. 5 (1998), https:// journal.fi/tt/article/view/58564.

22 Jalava and Kettunen, "Epilogi."

${ }^{23}$ Central Intelligence Agency, Finlandization in Action: Helsinki's Experience with Moscow. Reference Title: ESAU LVI. RSS No. 0059/72 (1972), ii, https://www.cia.gov/readingroom/docs /esau-55.pdf. 
historical term as it is used today, Finlandization has become accepted in the sense that today it can be used as a metaphor in political arguments by all sides, regardless of their political hue; former communists may use it as much as other politicians. It can be used to refer to any phenomenon whose general logic can be likened to Finland's historical power relationship with the Soviet Union. Furthermore, although it was originally coined in West Germany, the term has become a part of public discourse and national historical imagination in Finland. The term Finlandization is accepted because it brings together - under the central national narrative - various sides of Finland's post-WWII story, in which economic growth, building of the welfare state, and a balancing act between the West and the Soviet Union went hand in hand. In other words, Finlandization is not understood as a break or discontinuity in a unified national narrative even though it raises critical questions about that narrative. It retrospectively reflects the past contestations that took place in the process of maintaining national continuity. These contestations are now understood as painful but accepted historical necessities or collateral damage in a struggle for national survival. As part of the institutionalized version of Finnish history, of politics of history, Finlandization is thought to embody the connections and conflicts between various sides of society and how their linkages in the past in fact led to a unified present. Finlandization has become a part of a collective memory of the past from which the Finns have learned and continue to learn and thereby, also, continue to strengthen the unity of the nation in the present. Bringing Finlandization up every now and then is simply a reminder not to get into the same pickle again, and yet it refers to the success of getting out of that pickle. It reminds the Finns that their nation persevered successfully through the Cold War. The term implies that divisive actions taken at the time can be criticized but should not be understood as fundamentally opposed to national unity or Finland's historical continuity.

The historical examples that remain excluded from the central narrative also relate to the relation of domestic and foreign policy and similarly raise questions about the history of national sovereignty and independence. These are not the actions that the Finns took to maintain their fragile or diminished sovereignty, but the variety of efforts the Finns undertook to relinquish themselves of that responsibility for the perceived good of the nation, especially between 1917 and 1945. Some key moments include debates over democratic rule vis-à-vis sovereign power (democracy as incompatible with sovereignty) in Finland all the way up to American and British recognition of Finnish independence in May 1919. Another is the conclusion of treaties by the Left and the Right with foreign powers during the civil war. Yet another is the adoption of an authoritarian 
constitution for the Prince of Hessen whom the victorious bourgeois side elected as King of Finland after the civil war. A final example is the politics that aligned Finland with Nazi Germany and included ideas of a Greater Finland. Approximately 1,400 Finnish volunteers joined the Waffen-SS and fought for Germany outside of Finland. ${ }^{24}$ In contrast to Finlandization, which today stands as a reminder not to allow external challenges to undermine national unity, these other moments in Finnish history are still understood to drive a wedge between a united past and the political pluralism of the present. This is true even though at the time those actions were no more and no less problematic or confrontational from the perspective of sovereignty than Finlandization was. Furthermore, academic research conducted on these histories is rarely cited in the public debate as part of Finland's institutionalized politics of history. In Finland, they are not understood as parts of more general historical processes and are not considered a part of a common national history, even if outside of Finland, from a global and comparative history perspective, they are just as much a part of Finnish history as Finlandization.

Kettunen has described this difference as arising from Finland's particular rules of national memory regarding truths and facts, and "the correct order of remembrance" of the relations between different national truths and facts. ${ }^{25} \mathrm{In}$ simple terms, Finlandization gathers various national truths under the same umbrella of historical continuity, whereas the idea that the victors in Finland's civil war did not want an independent Finland, in the sense of post-1919 nationstate sovereignty, disrupts the order and connection of truths in the collective national narrative and memory. For example, independence is given priority over histories of collective violence. Historical considerations that challenge this "correct order" are seen as disrupting the "democratic" stability and the national consensus that are features of the Finnish politics of history.

These are of course particular examples of prioritization, and the politics of history is replete with other similar cases, ideas and events. Many of them are less poignant or less well-known. They include concepts and ideas that are openly included, like Finlandization, and others that are excluded, like efforts to avoid sovereign independence. Some events and processes are forgotten or occluded, and perhaps never researched or learned about. Overall, the main line of exclusion in the processes and practices of history politics is drawn in favor

${ }^{24}$ See for example Simo Muir and Hana Worthen, eds., Finland's Holocaust: Silences of History (New York: Palgrave Macmillan, 2013).

25 Kettunen, "Kansallinen 'me' ja historia globaalistuvassa maailmassa," 1-8. 
of historical knowledge that enforces continuity. It is drawn against historical knowledge that would question, pluralize or problematize national historical continuity. In this regard, Finland differs somewhat from other countries, such as those described by Zubrzycki and Woźny, where discontinuous or disruptive narratives are not excluded from the politics of history, even when they have been politically targeted or even denied altogether as actual history. ${ }^{26}$ The way those countries deal with alternative historical knowledge amounts to a more open history politics, even when it leads to political refutation or exploitation of those views. That is not to say that other countries' history politics are better or worse than Finland's, but rather that, like other democratic processes, a participatory and democratic history politics cannot be assumed to automatically follow from institutional design. In other words, the insistence on "correct order," and strict and exclusionary gatekeeping in the processes and practices of history politics, results only in what may seem at first glance more equal and less politicized fora for the politics of history in Finland than the "open door" situation in other countries. However, the insistence on institutional stability restricts open and inclusive participation. A focus on the civility and openness of discussion and debate at the fora of the politics of history is maintained in Finland by keeping dissonant or disruptive voices outside, by restricting participation.

\section{The Finland 100 Celebrations}

Regarding Finnish independence day celebrations in general, Heino Nyyssönen says they are "exceptional in present day Europe" because of their strong association with war and the solemnity of national remembrance "strongly bound to tradition." ${ }^{27}$ As we shall see, while the organizers of the 100th anniversary celebrations aimed to produce a more cheerful atmosphere of commemoration, they did not succeed in fundamentally changing the event aside from encouraging greater participation, according to the analysis commissioned by the Prime Minister's Office. ${ }^{28}$ One telling example of this is a project known as

${ }^{26}$ Zubrzycki and Woźny, “The Comparative Politics of Collective Memory”. Zubrzycki and Woźny discuss specifically the German, Japanese, Polish, American, and Turkish cases.

27 Heino Nyyssönen, "The Politics of Calendar: Independence Day in the Republic of Finland," in National Days: Constructing and Mobilising National Identity, ed. David McCrone and Gayle McPherson (New York: Palgrave Macmillan, 2009), 136-137.

28 Ruokolainen et al., Suomi 100 - Juhlavuoden vaikutukset: Osa 1. Valtioneuvoston kanslian julkaisuja 10/2020, http://urn.fi/URN:ISBN:978-952-287-905-9. 
the "Guards of Honor," in which young people in several cities were recruited to perform "emotional ceremonies" over the graves of "the deceased heroes who safeguarded Finland's independence." 29 This type of activity simply expanded on the solemn, traditional nationalism inherent in previous Finnish independence day celebrations. I suggest that there is a similar dynamic going on in the country's history politics, as expressed through the celebrations.

The official purpose of the extensive celebrations around Finland's 100th independence day, according to its main organizer, the Prime Minister's Office, was to collectively "celebrate Finnish democracy, equality and a strong civil society." 30 The organizers specified that the project would "reflect on the past 100 years of Finland's independence, assess its present and explore its future." 31 The project thereby took on a very active and intentional history political stance. It even began planning the celebrations' own historical future by proclaiming them to set a "legacy for the next 100 years." ${ }^{2}$ From the beginning, the project aimed to make the 2017 event a historic one. The participants were guided to document their activities for later research. ${ }^{33}$

This centennial was to provide an "opportunity to take a fresh look at life" through the "history of an entire nation" in order to "evaluate our current circumstances, make changes, and plan for the future." 34 Other stated goals of the project were increasing the inclusivity, openness and diversity and strengthening the feeling of "belongingness" in Finnish society, with the theme "together" and the "spirit of togetherness." 35 Afterwards, the organizers deemed their effort successful: "As the year went on, the significance of the together theme grew deeper and broader, until it defined every aspect of the celebrations ... [which] grew into an exceptionally prominent and inclusive event," that "provoked wide debate."36

The organization of the celebrations was launched in 2011 when a committee was set up to prepare a memo containing suggestions for the upcoming celebrations. The memo, delivered in 2012, suggested that the anniversary events "contemplate the various sides of the independence process through various events" and highlight "the connections of Finnish independence with similar

\footnotetext{
29 VNK, Suomi 100 vuotta. Yhdessä. Suomi 100 -juhlavuoden raportti, 60.

30 Suomi 100-hanke ja VNK, Opas Suomi 100 -ohjelmahankkeille (March 2017), 2.

31 Ibid., 17.

32 VNK, Suomi 100 vuotta. Yhdessä. Suomi 100 -juhlavuoden raportti, 83.

33 Suomi 100-hanke ja VNK, Opas Suomi 100 -ohjelmahankkeille.

34 VNK, Suomi 100 vuotta. Yhdessä. Suomi 100 -juhlavuoden raportti, 7.

35 Ibid., 5, 9, 13, 31, 64.

36 Ibid., 5.
} 
events elsewhere in Europe." ${ }^{37}$ Except for an academic conference organized in 2017, in which I also participated, ${ }^{38}$ in the end these initial themes regarding the history political stance of the celebrations were not connected to the overall organization. Comparative contemplation representing various aspects of the Finnish independence process was not present. Any such contemplations were relegated to a few academic events, which indicates that the most popular celebrations were used to shape a purposeful, monolithic politics of history around Finland's independence. The history politics that emerged was quite different from what was originally planned. ${ }^{39}$ The lack of methodological nationalism even caused a scene at the one academic conference. During one of the keynote speeches, a participant began to loudly protest the lack of focus on Finnish achievements and a "Finnish history," as I witnessed firsthand.

One of the main objectives of the Finland 100 project was, in fact, to "showcase success stories from Finland," of which there were plenty to be found "if the focus was on a historical perspective," in the words of the organizers. ${ }^{40}$ In their eyes, the way the present and specifically Finnish independence was presented in the celebrations was the main determinant of their success. Historic events and processes that might have distracted from the orderly image of an ultimately successful and triumphant past were ignored. This aspect was enforced in the theme of the celebrations as "harmonious coexistence of different perspectives, practices, and contributors." ${ }^{11}$ This policy reminded me of the propaganda that I witnessed on display at a permanent exhibition of the national history museum of Uzbekistan in late 2019, where five different political parties in harmonious co-existence seek the good of the nation. In the Finland 100 celebrations, differences were papered over within a unified historical narrative of Finnish independence. For example, an expensive video advertisement commissioned for the celebrations promoted the image of a vast, unified past of great solidarity, which

\footnotetext{
37 Ruokolainen et al., Suomi 100 - Juhlavuoden vaikutukset: Osa 1., 15.

38 Reform and Revolution in Europe, 1917-19: Entangled and Transnational Histories Conference. University of Tampere, Finland, 16-18 March 2017.

39 The project was launched under a Left-Right coalition government but was finalized and implemented under a Right-Populist government. However, the literature produced so far suggests that the Finland 100 celebrations represent a continuity of other similar politics of history. It is hard to say whether a Left-leaning coalition would have been willing to diverge from such institutionalized politics of history and actively press for a more open history politics in connection with the Finland 100 celebrations.

${ }^{40}$ VNK, Suomi 100 vuotta. Yhdessä. Suomi 100 -juhlavuoden raportti, 11.

${ }^{41}$ Ibid., 40.
} 
the advertisement then went on to project into the future. ${ }^{42}$ This advertisement was typical of the way the relation of past and future was painted throughout the celebrations; a straight and narrow path marked out by a one-way arrow pointing from the past, through the present, and into the future, along which Finland was being propelled forward by its history of successful national development.

The celebrations had a strong international component organized under the banner of the "Finland Brand." 43 Over 500 projects and thousands of events took place outside of Finland with the aim of "raising Finland's international profile" and seeing "the Finnish flag hoisted in every corner of the world." 44 The events were organized in cooperation with the Ministry for Foreign Affairs and Finnish embassies abroad. One of the more striking examples was the projection of the Finnish flag onto the surface of several famous monuments worldwide. For example, the colosseum in Rome was lit up in blue and white, and the event was broadcast live on national television in Finland. Interviewed on the evening news, the Finnish ambassador to Italy explained joyfully to the audiences at home that to him, seeing the Finnish colors on the Colosseum confirmed how Finland's 100-year history is "part of a western tradition that began in antiquity." 45 The event at the Colosseum was an example of the active mobilization of the celebrations by the state to promote highly dubious and populist interpretations of history in Finland.

The international events and their promotion and "branding" of the "story of Finland" reflects also the strong influence of consultancy and marketing agencies employed in the organization of the celebrations. Their efforts were even awarded a prize as Finland's "communication act" of the year. ${ }^{46}$ Similarly, the celebrations' initial focus on inclusivity was understood and measured simply as coverage and reach through detailed quantified data of the amounts and varieties of events organized and the audience they attracted. This served only to highlight a lack of focus on the quality and diversity of the contents. Marketing

42 "Suomi Finland100 - Believing in the Impossible," YouTube video, 1:00, posted by SuomiFinland100, November 15, 2017, https://www.youtube.com/watch?v=L4DxP0irRy8.

${ }^{43}$ VNK, Suomi 100 vuotta. Yhdessä. Suomi 100 -juhlavuoden raportti, 105.

44 Ibid., 5, 49.

45 See for example Juho Korhonen, "National Self-Determination before and after 1917: the Case of the Grand Duchy of Finland of the Russian Empire" (Presentation at the Constellations of Empire, Nationalism and Revolution in 1917 and 2017 Conference, Watson Institute, Brown University, Providence, RI, USA, December 8, 2017), https://watson.brown.edu/events/2017 /constellations-empire-nationalism-and-revolution-1917-and-2017.

46 "Suomi 100 on Vuoden viestintätyö - SEK ja valtioneuvoston kanslia tekivät vuosisadan keikan," official site of The Finnish Association of Marketing, Technology and Creativity (MTL), June 15, 2018, https://mtl.fi/2018/06/suomi100-on-vuoden-2018-vuoden-viestintatyo/. 
and brand management considerations are beyond the scope of this article, but the approach advocated by the marketing professionals likely contributed to Finland 100's carefully curated, one-sided narrative of an unquestioned national past culminating in an admirable present day society. For example, extensive communications manuals were prepared for the use of the various companies, associations and other participants of the celebrations. These manuals included instructions on how to "avoid crises," which included advice to monitor the tone of conversations and to contact the Finland 100 central communications office if even "weak signals" of emerging problems were detected. ${ }^{47}$ The organization thus sought to pre-empt any criticism of the way in which the celebrations were managed and what they represented.

The desire for control of the message also comes through in the self-assessment by the Finland 100 organizers of the results of their efforts. According to the initial reporting, a "positively open and pluralist Finnishness" underlined the celebrations. ${ }^{48}$ This was apparently exemplified by how "playfulness was evident alongside the more traditional formality" and in how "national identity and national self-esteem were more clearly defined on the basis of Finn's own values rather than on a definition of exclusion, by which we use other countries or nations as benchmarks for what we are not." 49 This long-winded, rather self-absorbed take on national identity is reminiscent of self-help guides and norms of schoolyard behavior. It exemplifies the lack of intent and effort to grapple with complicated, contested issues of nationalism. It indicates a straitjacketed approach to promoting, yet not openly debating, an essentialized national history. This same approach and oxymoronic marketing speech was repeated throughout the organization efforts. For example, in 2013 the Prime Minister's Office issued instructions that the celebrations should inform, teach and discuss "the central values and principles, on which Finnish democracy's pluralistic values are founded." 50 Yet, the politics of history of the Finland 100 celebrations were organized so that no such discussion was possible. For example, in the celebrations the history of Finnish democratization was conflated with the sovereignty of the nation-state, although they arose quite separately in Finnish history. Finland had implemented universal suffrage as one of the first states in the world in 1906 and 1907 under the Russian Empire. Independence followed

\footnotetext{
47 Suomi Finland 100. Viestintäopas, April 1, 2016, https://www.riihimaki.fi/wp-content/uploads /sites/3/2016/05/Suomi-100-Viestintaopas-2016.pdf.

${ }^{48}$ VNK, Suomi 100 vuotta. Yhdessä. Suomi 100 -juhlavuoden raportti, 86.

49 Ibid.

50 Ruokolainen et al., Suomi 100 - Juhlavuoden vaikutukset: Osa 1., 16.
} 
over ten years later and in a manner that jeopardized Finland's earlier democratic development. Nevertheless, the Finland 100 celebrations advanced the theme of democracy as integral to Finland's independence in the form it took starting in 1917-19. Nationalism has a complex and conflict ridden relationship with democracy everywhere, not only in Finland. Yet the Finland 100 project papered over these questions and promoted Finnish exceptionalism with disingenuous ideas like that of national "values and principles" that make Finnish democracy essentially pluralistic.

The initial report on the results of the project, put together by its organizers, begins with bold statements about Finland's history and makes similar claims to those of the traditional nationalist historiography. It locates the agency of state-making and independence in the nation and in the hands of the Finns. For example, it dates the start of joint Finnish "decision-making," as they term it, ${ }^{51}$ in independence that it claims started in December 1917. The project immediately sweeps under the rug historical contestations over independence and domestic politics at the time. More importantly, such a portrayal suggests that the civil war period in 1918 was part of the Finns' harmonious joint nation-building and decision-making. The organizers ignore the fact that Finland's Independence Day itself was a creation of the winners of the civil war. It was a highly politicized act that sought to erase the memory of the part the Left played in the formation of the state and in the Finnish struggle for autonomy and independence. An alternative interpretation, more in line with democratic history politics, would have highlighted the multiple struggles, contestations and interconnected politics through which the Finnish state-building process passed. What highlights the intentionality of this choice by the organizers is that this historical knowledge is readily available to the lay public in Finland. The organizers' interpretations did not result from a lack of knowledge.

Tellingly, only one historian's voice is present in the documentation and research that has so far been produced by the organizers of Finland 100 and the Prime Ministers' Office. Historian Antti Häkkinen was asked to provide a less than a page of opinion about the celebrations as part of the organizers' first self-evaluation, which he prepared under the guidance of the organizing authorities. In the project's self-assessment, Häkkinen writes the following: "I believe - and the research supports this - that a kind of neo-patriotic movement has been strengthening for a long time. The centenary year gave it new and fresh forms of expression. It is patriotism reimagined. Let's hope the content is not just

51 VNK, Suomi 100 vuotta. Yhdessä. Suomi 100 -juhlavuoden raportti, 5. 
the same old story." ${ }^{2}$ Häkkinen's brief contribution to the report has a sharply different, more critical and more analytical tone than other texts produced or commissioned by the Prime Minister's Office about the celebrations.

Ultimately, Häkkinen's wish that the celebrations would not reproduce the "same old story" was thwarted by the highly controlled, undemocratic history politics championed by Finland 100's present-day-focused, tightly curated program. The consequences of focusing on the present and dismissing an open and pluralistic understanding of the history of Finnish nationalism were summed up well by Häkkinen: "It appears to be a positive process of liberation [from a stricter traditional patriotism], though it may not end this way. Moments of madness have their dark side. They can also be targeted at others, they can divide and create otherness." He ends by stating that a "research-based in-depth study on the mental structures [behind this neo-patriotism] is badly needed." 53

The first report of the extensive follow-up research on the celebrations commissioned by the Prime Minister's Office came out in $2020 .{ }^{54}$ The one-hundred-page report assessed the effects of the celebrations on Finnish society. The research was funded by an approximately 200,000 euro budget. It drew its conclusions from eleven research and documentation projects that were conducted as Finland 100 was being organized. The report did not contain any assessment of the project's impact on the public's historical knowledge, nor did it talk about history politics. The relation of the Finland 100 celebrations to the past and to history has so far not been assessed anywhere else in the reporting, with the exception of Häkkinen's half-page of critical remarks. This despite the fact that the organizers themselves, chief among them the Prime Minister's Office, called the entire Finland 100 project a "historically exceptional phenomenon," that will "go down in history" with "historically great impact and extent." 55 Again, we find a mismatch of rhetoric and action that is reminiscent of many other intersections of propaganda and undemocratic politics.

The Prime Minister's Office issued strict guidelines and focus points for further research on the celebrations. They do not mandate seeking answers to any critical or historical political questions. Rather, the Office's focus is on whether the celebrations promoted "Finnishness," without defining that term,

52 VNK, Suomi 100 vuotta. Yhdessä. Suomi 100 -juhlavuoden raportti, 106.

53 Ibid.

${ }^{54}$ Ruokolainen et al., Suomi 100 - Juhlavuoden vaikutukset: Osa 1.

55 Ruokolainen et al., Suomi 100 - Juhlavuoden vaikutukset: Osa 1, 83-84; and "Suomi 100 -juhlavuoden laajuus ja vaikutukset historiallisen suuria," Prime Minister's Office, September 25, 2018, https://vnk.fi/-/suomi-100-juhlavuoden-laajuus-ja-vaikutukset-historiallisen-suuria. 
on identifying "lessons learned" that can be useful for organization of similar "large thematic events" in the future, and "activating citizens." Another objective for further research is cementing in place the "national cultural capital" that the Finland 100 project created. ${ }^{56}$ Finally, the research is supposed to provide suggestions for increasing this type of impacts of the project. ${ }^{57}$ Unfortunately, a critical academic research approach to the celebrations is missing from the guidelines for follow-up research. Rather, the guidelines demand that the celebrations be taken at face value and their success be evaluated in that limited framework. The Prime Minister's Office is in no uncertain terms using public funds to commission research into how to encourage citizens and civil society to be more active in accepting and promoting a particular and politically questionable version of Finnish nationalism. There is one lonely sentence in the Prime Minister's call for papers that promotes diversity, which reads: "The starting point of study is the cultural diversity and multilingualism of Finland." 58 This sentence stands alone in its own paragraph. The rest of the text does not specify the way cultural diversity and multilingualism should be a part of the research. Nor does it suggest that the celebration of cultural and linguistic diversity implies anything other than an uncontested, immutable, monolithic national narrative.

The guidelines issued by the Prime Minister's Office, which seek to ensure the replication of the national cultural impacts of the celebrations in the future, actually bring into question the scientific impartiality of the research on their outcomes. The report on the celebrations nevertheless contains evidence about how they were organized, which is useful for the purposes of this article when analyzed from the perspective of history politics.

The preparations for Finland 100 coincided with the onset of the 2015 refugee crisis in Europe and the rise of populist right-wing parties in Finland and elsewhere in Europe. According to interviews conducted for the report, the rise of right-wing sentiment was concerning to the organizers, who feared that the celebrations might take on an unwanted nationalistic undertone, contrary to their desire to feature multiculturalism as an asset of contemporary Finland. ${ }^{59}$ These worries led the organizers to stress that Finland 100 would be a "positive"

\footnotetext{
56 Suomi 100 -tutkimushanke, Prime Minister's Office, accessed November 15, 2020, https://vnk.fi /suomi-100-tutkimushanke.

57 The research projects were still continuing in early 2021. The Social Democrat-led center-left coalition that took power in 2019 has so far not commissioned any new studies that would have a broader focus or include historical political research.

58 Suomi 100 -tutkimushanke.

59 Ruokolainen et al., Suomi 100 - Juhlavuoden vaikutukset: Osa 1., 17.
} 
celebration of "all Finns and friends of Finland." They made a deliberate effort to avoid, or "bypass" as one interviewee in the study put it, the question of whether the celebrations were only for Finnish citizens. ${ }^{60}$ The goal of "positivity" was perhaps achieved from a public relations perspective. However, it carried with it a telling hint of avoidance rather than engagement with sensitive issues. These included how the celebrations should deal with the politics of history, nationalism, the construction of the Finnish nation-state, and national historical myths. If national independence is not at the heart of debate, discussion, and assessment of the identities, histories and myths surrounding "who the polity is for," then what is? But the organizers wanted to present an independence that was supposedly far-removed from all the contentious ideas that give meaning to the concepts of a nation and a nation-state.

History politics do not receive any attention in the extensive comparisons that the report on the outcomes of Finland 100 makes with previous Finnish independence celebrations and with similar celebrations in other countries. This despite the use of comparative historical data in the analysis. Rather, the focus of the report is on the instrumentalization and the functional role of the celebrations, and on their reach and impact. This approach is akin to functionalist and modernization theories. Even more so, the reporting focuses uncritically on how organization and lessons from previous celebrations have been used and applied. ${ }^{61}$ In a brief overview, the report shows how since 1967, Finnish independence celebrations have expanded their ideas about what constitutes the national framework and identity. They incorporated more and more aspects of life under their umbrella: the report states that independence celebrations have moved from being state-centric to being a wider celebration of "the Finnish way of life." 62 The 100th anniversary, with a stated goal of being the historically most capacious and extensive event of its kind, ${ }^{63}$ then fits neatly into this trajectory of portraying and understanding more and more aspects of lived experience as representations of nationality and nationalism in unchanged functionality from 1967. That trajectory is very much in contrast with recent developments in historical research, which emphasize connected histories and transnational forces and networks, not to mention earlier, well-established works on the invented and socially constructed nature of nationalism.

\footnotetext{
60 Ibid.

${ }^{61}$ Ibid., 19.

62 Ibid.

${ }^{63}$ Ibid., 20.
} 
In the vein of invented and constructed nationalism, the organizers of the celebrations sought out and brought in ideas from elsewhere for expanding and extending the celebration of nationality. Their report cites Norwegian celebrations in which immigrants were dressed in Norwegian national costumes and the movies that the Estonian state commissioned to celebrate its independence. ${ }^{64}$ The organizers actively reflected upon the Finnish historical trajectory as one comparable and commensurate with a universal notion of national development and fitted local contexts and narratives into this framework. However, important differences can be seen in the way Estonia celebrated the centennial of its 1918 declaration of independence with the historical sensitivities that a post-Soviet context brings. Canada, another source of inspiration to the organizers, treated the idea of civic participation very differently than did Finland 100. It accommodated a critical and problematizing approach to the country's history as a nation of colonial settlers and later of immigrants. Indeed, as the report shows, Canada grounded its celebrations in an introspective understanding of its internal plurality (requiring participation by first nations and other ethnic or language minorities), while Norway grounded its celebrations in its constitution. ${ }^{65}$ Such critical approaches were glaringly absent from the Finnish celebrations and were clearly dropped in the process of supposedly learning from these examples. Rather, questions about the legacy of democracy, struggles over the framing of the constitution, and minority histories were subsumed into a narrative of Finnish national unity. For example, Sami perspectives running against the grain of the national narrative were relegated to the academic realm or fully excluded. ${ }^{66}$

Despite a thorough preceding discussion suggesting otherwise, the report in the end interprets the more critical focus on national history in Canada and Norway as essentially nationalistic. The report's conclusion hews to the political guidelines about the replicability of promoting Finnish nationalism that the report's authors were given. For example, the report claims that in Norway, the "integral focus on history, information, and possibilities for citizens' mobilization and civic activity" is a sign of nationalism. ${ }^{67}$ The report thus supports the underlying intent of the Finland 100 celebrations and their organizers to restrict

${ }^{64}$ Ibid., 23.

65 Ibid., 24.

${ }^{66}$ See for example Reetta Toivanen, “Sápmi Saami 100," Voima (February 6, 2017), https://voima.fi /hairikot/artikkeli/sapmi-saami-100/; Jukka Nyyssönen, Pigga Keskitalo, and Tiina Kinnunen, "Sápmi 100? Saamelaishistorian vastanarratiivejä Suomi 100-tapahtumassa Sajoksessa," Ennen ja Nyt 2 (2018), https://www.ennenjanyt.net/2018/09/sapmi100-saamelaishistorian-vastanarratiiveja -suomi100-tapahtumassa-sajoksessa/.

${ }^{67}$ Ruokolainen et al., Suomi 100 - Juhlavuoden vaikutukset: Osa 1., 26. 
participation and the diversity of perspectives, especially when it comes to historical interpretations surrounding Finland's independence and nationalism. They preferred to steer clear of problematic and divisive interpretations of the past. In so doing, the planning of the celebrations, the celebrations themselves, and the after-action reporting on them represent an effort to control Finland's history politics and troubled pasts. The only mechanism present for inclusion is the acceptance of a widening national historical framework, whose premises are not openly contested. Finland 100's consideration of independence through "history, the present and the future" translates into an enforced narrative of a unifying national framework, instead of an open and democratic discussion of the contested meanings of independence and nationalism - and possible changes to them. An open discussion would require giving space to a variety of interpretations and imaginaries of Finland's history and its connections with the present and the future.

As the report states, the theme and objective of the celebrations of Finland's centennial "do not differ from previous anniversaries," except that they sought to mobilize Finnish society more intensively. ${ }^{68}$ Nevertheless, it presents Finland 100 as a non-nationalistic project, or at least less nationalistic than elsewhere, despite the fact that the stated goal of the Prime Minister's Office was cementing Finland's national cultural capital. ${ }^{69}$ Historical research on Finnish nationalism and independence, and the knowledge and interpretations of its history, have significantly changed over time, sometimes through painstaking and politicized debate. By contrast, the state-organized independence celebrations have kept to a singular trajectory, only expanding their size, reach, and pervasiveness. For history politics regarding Finland's independence and the celebrations that are aimed at bringing state and citizen together, historical research (not to mention alternative and marginal histories) has had little effect on ideas about independence and nationalism. This indicates that in Finland, the official politics of history has successfully been kept static and uncontested, along with a monolithic, exclusionary history politics. ${ }^{70}$

68 Ibid., 22.

${ }^{69}$ Indirectly, the report does in fact achieve one goal set by the Prime Minister's Office by falsely presenting Finnish nationalism and its history as objectively determined, colorless, and unifying.

70 Similar conclusions have been expressed about Independence Day and other celebrations in Finnish schools. Niemi et al. argue that these celebrations are considered to be important to creating "a sense of national or cultural community," but that they overlook the "intercultural potential." Pia-Maria Niemi, Arniika Kuusisto, and Arto Kallioniemi, "Discussing school celebrations from an intercultural perspective - a study in the Finnish context," Intercultural Education 25, no. 4 (2014): 255, doi: https://doi.org/10.1080/14675986.2014.926143. 
Based on the studies the Prime Minister's Office commissioned to determine the effects the Finland 100 celebrations had on Finnish national identity and civil society, no goals, practices, or forms of participation for defining historical questions or introducing alternative perspectives were specified beforehand. Besides allusions to contemplation of comparisons and multiple sides in the early memo mentioned, the entire organization of Finland 100 was that way from its inception. It was silent about its own history politics even though it placed heavy emphasis on inclusiveness, togetherness and diversity that supposedly build on a shared past. This amounts to a controlled, non-democratic approach towards history politics in the Finnish national context. The massive 100th anniversary of independence celebrations are perhaps the clearest example and reflection of the prevailing situation and especially of the current developments and trajectories of Finnish history politics in general.

\section{Finland 100 and International Comparative History Politics}

Analyzing the Estonian case from which the Finland 100 organizers also claimed to have drawn inspiration, Karsten Brüggemann and Andres Kasekamp note that in an open society it should be "hardly possible to pursue "the one and only' narrative any more" and to "exclude divergent interpretations." ${ }^{11}$ It is in the comparison with Estonia, a neighboring country and nation that represents a historically close comparative case with Finland, that we can detect contrasts that are descriptive of the Finnish case. While Estonia was a part of the Soviet Union and took a strong nationalist turn in its politics of history after the fall of the Soviet Union, representative of post-socialist countries in general, Finland had remained independent but was within the Soviet sphere of influence. And while Estonia had to first break and then come to terms with its past after 1989/91, Finland went through a similar but much less shocking reorientation that did not force an open confrontation with the politics of history, especially in the public sphere. On the contrary, earlier critical perspectives towards Finnish history politics and the politics of history were dismissed as having been caused by a need to appease the Soviets. Jouni Tilli, for example, says that the political character of certain key historical interpretations "has been somewhat

${ }^{71}$ Karsten Brüggemann and Andres Kasekamp, "The Politics of History and the 'War of Monuments' in Estonia," Nationalities Papers 36, no. 3 (2008): 425-448, doi: https://doi.org/10.1080 /00905990802080646. 
neglected ... often in ways that deny the political character of historiography."72 In contrast, as Brüggemann and Kasekamp argue, Estonia has made major strides in "deconstructing the once dominant narratives of suffering nations," and in coming to terms with its troubled past and a divided historical memory in the public sphere (beyond academic historical research). ${ }^{73}$ This has led to open contestation, debate and conflict over the politics of history and to clashes of history politics in a process headed towards the "democratization of memory" over the "sacralization of memory." 74

The Finland 100 project shows that although the state and other entities may not aim directly at the sacralization of a unified narrative, their motivation and conception of supposedly non-nationalistic politics of history is to avoid the democratization of memory; diversity in the present is added and included into an unchanging and untouchable past. Different narratives and perspectives do not clash and there is no contest in the present over "historical truths," accurate and informative interpretations or alternative perspectives. The situation increases the distance between the sphere of academic historical research and the public sphere. The disputes which have flared up in post-socialist countries are inevitable when the politics of history have been similarly torn asunder, but in Finland such disputes are interpreted as problematic if not shameful failures because they are viewed through the lens of an imagined acceptance of diversity in the present that is premised on an untroubled past.

Matti Jutila has described this as a "securitization of national identities," meaning that simplified historical narratives are used to present "a more unified image of the nation than what would be historically accurate." 75 Opening up the past to both more diverse conceptions and to previous exclusions would in fact desecuritize rather than reify or undermine national identities, Jutila explains. ${ }^{76}$ However, it would appear that the type of history politics promoted by the Finland 100 project perceived this as a threat to the marketability of the putatively diverse Finnish national identity in the present, and opted rather to put everything under the umbrella of the Finnish nation rather than to democratize the politics of history concerning that umbrella.

72 Jouni Tilli, "Elina Sana's Luovutetut and the Politics of History," in Finland's Holocaust: Silences of History, ed. Simo Muir and Hana Worthen (New York: Palgrave Macmillan, 2013), 164.

73 Brüggemann and Kasekamp, "The Politics of History," 427.

74 Ibid.

75 Matti Jutila, "Securitization, history and identity: some conceptual clarifications and examples from politics of Finnish war history," Nationalities Papers 43, no. 6 (2015): 941, doi: https://doi.org /10.1080/00905992.2015.1065402.

76 Ibid. 
The story of a bar owned by a Finn in Berlin was a telling example of the state of Finnish history politics. It was found that the Finnish owner belonged to a society that memorialized Finnish soldiers who served in the Waffen-SS during World War II. The bar owner had posed for pictures with his father's SS-helmet. In Berlin this led to boycotting of the bar, while in Finland, the case was considered a curiosity and a matter of cultural differences in historical understandings. No similar activity towards the main branch of the bar, located in Finland, took place. The bar owner described his membership in the memorial association, and the association itself, as purely a neutral and apolitical matter of "historical remembrance," unconnected with present-day politics. Interestingly, his explanation resonated with a Finnish kind of logic in which Germans could simply not be expected to understand that in Finland the interpretation of history was different. This logic excluded the possibility that the Finnish and German politics of history, not to mention their histories themselves, might be connected. Finnish news articles about the case rushed to point out that displaying Nazi symbols is not a crime in Finland as it is in Germany. The Finnish press steered clear from the actual politics of history of SS-commemoration. At times it repeated, without reference, the historically false and problematic statement that the Finnish SS-volunteers did not necessarily know that they were specifically joining the SS-troops and that they were mainly motivated by anti-Soviet sentiment. ${ }^{77}$

As Tilli puts it, touching also upon Finnish actions in World War II, "Finnish historico-political debate has been hampered by an inability and unwillingness to understand how the consequences of a political atmosphere were permeated by profound nationalism." 78 Even the Finnish SS-volunteers fighting on the Eastern Front are depoliticized by portraying them simply as part of a unified Finnish defense against the Soviet Union. "The historiography of the Finnish Waffen-SS experience is imbued with a major paradox: the volunteers' involvement in the war on the Eastern Front tends to be understood in the domestic context ... as

\footnotetext{
77 See for example Visa Noronen, “Lammin Sahtikeisari Pekka Kääriäinen on kohun keskellä,” Hämeen Sanomat, March 10, 2019, https://www.hameensanomat.fi/uutiset/lammin-sahtikeisari -pekka-kaariainen-on-kohun-keskella-saksalaisjarjesto-vaatii-boikotoimaan-entisten-ss-miesten -apuyhdistyksen-aktiivin-ravintolaa-639964/; Solmu Salminen, "Suomalaispubia vastaan lietsotaan boikottia Berliinissä," Iltalehti, March 7, 2019, https://www.iltalehti.fi/ulkomaat/a/a42 e368a-43d7-442a-a5aa-6e5e8b5dc50b; Anna Saraste,"Suomalainen olutravintola boikotin kohteena Berliinissä," YLE, March 9, 2019, https://yle.fi/uutiset/3-10681429; Ines Siren,"SS-perinnettä vaalivan yrittäjän baari suljetaan Berliinissä," Helsingin Sanomat, September 10, 2019, https:// www.hs.fi/kaupunki/art-2000006233727.html.

78 Tilli, "Elina Sana's Luovutetut and the Politics of History," 152.
} 
though the Waffen-SS volunteers were in effect fighting on the Finnish front."79 According to this interpretation, Antero Holmila specifies, all those soldiers can therefore be presented as identical and appropriated into the Finnish narrative. ${ }^{80}$ The "neutral" national narrative has the power to subsume even the Finnish Waffen-SS in a shared, uncontestably virtuous past.

\section{The Finland 100 Celebrations as History Politics}

Why would a democratic state like Finland be opposed to open, democratic history politics? When organizing, branding and promoting the once-in-acentury celebrations of independence (an important forum for the politics of history), and perhaps more interestingly, commissioning subsequent research into their impact on society, why would it fall back on a one-dimensional, deterministic narrative? Why would it continue to promote the politicized inventions of national tradition instead of information developed in more recent historical research?

The massive Finland 100 celebrations had as their stated goal spreading a message of the diversity and inclusiveness of modern Finland. That message was carefully curated and with great resources woven on top of a singular and history politically undemocratic interpretation and representation of the past. As Eemeli Hakoköngäs summarizes critically, the theme "together" did not encourage any critical perspectives and few opinions were raised that would have inquired about the actual historical construction of the understanding of Finnishness. ${ }^{81}$

The government-organized celebrations actively avoided discussion of contested aspects of Finnish history. Instead, they sought to bring everyone "together" under a non-transparent and closed narrative of national history that made present day diversity and inclusiveness hinge on a non-historicized and exclusionary process of how the past is understood and connected to the present. The stated aim of the massive organization effort, the public relations, and the media coverage was to gather separate and even contradictory aspects of Finnish history, past and present, under the same umbrella of "positive," "successful" national

79 Antero Holmila, “'Soldaten wie andere auch': Finnish Waffen-SS Volunteers and Finland's Historical Imagination" in Finland's Holocaust: Silences of History, ed. Simo Muir and Hana Worthen (New York: Palgrave Macmillan, 2013), 219.

80 Ibid.

${ }^{81}$ Eemeli Hakoköngäs, "Arvostelut: Soturikansasta rauhanrakentajaksi: suomalaisuuden myyttien historia," Kasvatus ja Aika 12, no. 1 (2018): 65-66. 
unity, togetherness and belongingness without critically questioning the history political work and exclusions that go into achieving such singularity.

Another key finding is that an open and democratic history politics was largely displaced by a focus on the celebrations themselves as a historical event in the making. For example, according to the official release of the Prime Minister's Office on independence day 2017, the celebrations "will remain in Finland's history as the most extensive and diverse jubilee year that Finns and friends of Finland created together." 82 This shifted the focus from what was celebrated to how it was celebrated and how the celebrations would look from a future standpoint.

The Finland 100 celebrations were an active history political instrument. The celebrations' relationship to politics of history was largely in line with the previous 50th and 75th independence anniversary celebrations, despite the celebrations' stated theme of "together" and the aim for diversity. Those earlier celebrations also steered clear of alternative historical narratives and did not open up historical conversations in a democratic manner any more than did the 2017 version. In the previous celebrations in 1967 and 1992, this meant that the events of the Finnish civil war and the histories of minorities were ignored and occluded. The traditional national historical narrative was repeated in the service of supporting a nationalist identity. The disappearance of Finland's close relations with the Soviet Union was the only factor that was substantially changed in $2017 \mathrm{com}$ pared to 1967 and $1992 . .^{83}$ To some extent, the missing Soviet factor enhanced the nationalist dimension of the 2017 celebrations. For example, historian Taina Uusitalo has shown that the celebrations included an increased idealization of the so-called Jääkäri-troops, trained in imperial Germany, who joined the civil war on the side of the bourgeoisie whites. The celebrations' positive portrayal of those troops contrasts with recent historical research on their role in Finnish history ${ }^{84}$ When historically marginal groups were incorporated into the national narrative, it took place without a historical discussion of their original exclusion and oppression, as Taavetti suggests regarding the homoerotic art of Tom of

82 Valtioneuvoston kanslia (Prime Minister's Office) Press Release, “The Finland 100 centenary reached its climax in Finland and around the world," December 6, 2017, https://valtioneuvosto .fi/-/10616/suomi-100-juhlavuosi-huipentui-suomessa-ja-maailmalla?languageId=en_US.

83 Kaisa-Leena Rahikka, “Suomi 50 ja 75 vuotta: historiapolitiikka juhlavuosina 1967 ja 1992” (Master's thesis, University of Helsinki, 2020).

84 Taina Uusitalo, “Jääkäriliikkeen diplomaatit historiantutkimuksen valossa 1914-1918," Ennen ja Nyt 2 (2018), https://www.ennenjanyt.net/2018/09/jaakariliikkeen-diplomaatit-historiantutkimuksen-valossa-1914-1918/. 
Finland. ${ }^{85}$ The relationship between past exclusion and present acceptance is glossed over by an appropriation of the past into a progressive developmentalist national narrative.

Throughout the planning, organization and reporting on the hundredth anniversary of Finnish independence, the state and key organizers have exercised control over history politics. They actively juxtaposed an open assessment of nationalism's history and its alternatives with the possibilities of a more inclusive nationalism today. Occlusion of the civil war and conflation of democratic developments with independence are telling examples of this strategy. Discrepancies or mismatches between past and present-day intentions and motivations are seen as possibly eroding a unifying national narrative.

This analysis confirms earlier research on Finnish independence day celebrations by Nyyssönen, who argues along similar lines in favor of a Finnish history politics that evaluates and judges the past from the present context, where the present is seen as "more advanced" and should therefore be kept a distance from any "unpleasant" pasts. ${ }^{86}$ Similarly, Holmila summarizes that Finnish historical culture actively ignores and avoids engagement with considerations of troubled pasts in order to cling to unifying myths and historical logics. ${ }^{87}$ The continued promotion of this type of undemocratic history politics can eventually transform the relation between the separated academic and public politics of history and lead to a political confrontation, as those two perspectives drift further apart from each other. This has the potential to lead to the political undermining of open historical research and knowledge. What is at stake in democratizing Finnish history politics, then, is, in fact, the real continuation of inclusive and democratic politics in the present and the future if, and when, the curated and mythical image of a unified national past crumbles.

Importantly, the stated goals of the celebrations were to "understand the past, observe the present and create a direction for the future." 88 This did not, however, entail support for transparent historical research or the promotion of recent findings and debates in the field. Rather, the celebrations, and the later reporting on them, promoted historical interpretations and memory politics that centered around a unilinear, deterministic reading of state sovereignty and independence, one that is more associated with the authoritarian states of the

85 Riikka Taavetti, "Suvaitsevaisuuden soturi. Tom of Finlandin ilo ja häpeä satavuotiaassa Suomessa," Ennen ja Nyt 2 (2018).

${ }^{86}$ Nyyssönen, "The Politics of Calendar," 137.

87 Holmila, “'Soldaten wie andere auch'”, 239.

88 VNK, Suomi 100 vuotta. Yhdessä. Suomi 100 -juhlavuoden raportti, 5. 
twentieth century than modern democracies. This was especially so since the argumentation and decision-making process leading up to these interpretations of history in Finland 100 was anything but transparent. The celebrations were meant to have reflected upon the past, but unlike the organizers claimed in their self-assessment, when it comes to history, they did not provoke "wide debate" 89 but rather cemented a particular hegemonic politics of history centered around an increasingly pervasive and expansive national narrative.

\section{Conclusions: History on Display, Look but Do Not Touch}

Though more research is required, based on my initial analysis, I identify the Finnish state as an active mnemonic actor, which, in light of the Finland 100 project and the kind of mnemonic regime that those actions imply, maintains an undemocratic history politics in relation to the country's politics of history. In short, the access of alternative or critical voices or historical perspectives to the national fora of the politics of history is strictly controlled.

Overall, we see that the Finnish state is a controlling, selective and coordinating mnemonic actor. Its history politics is constituted by two major separations that it seeks to maintain. First, in the public sphere and through its public relations work, the state, largely through coordination and cooperation with third parties, maintains discursive and epistemological control over how interpretations of the past connect with the present and the future. In simple terms, the influence of necessity on the events in national history is portrayed as having led to a more open present but only because the Finnish nation was monolithic and unified. This narrative allows room for stories of compromises made and conflicts avoided, such as Finlandization, but it excludes from national memory actions that could have undermined or prevented the "togetherness" of the nation.

Secondly, a separation between academic historical research and public historical interpretations is maintained. These two aspects and arenas of the politics of history, the public and the professional, are kept separate by the perception or an implicit logic of their incommensurateness. The belief is that keeping the two sides separate maintains the autonomy of both and that their interaction may undermine both of them. Pauli Kettunen has described this as an old Finnish tradition of understanding historians as the therapists of the nation, who selectively

89 Ibid. 
provide only positive impulses to the patient. ${ }^{00}$ So while the Finland 100 celebrations, for example, seek to reflect upon the past, they do so only in terms that are acceptable and understandable to the majority, which means actively interpreting everything through the lowest common denominator, that is, a colorless and immutable national framework. Anything outside this framework, or which may possibly undermine it, is thought to lead to "harmful" nationalism. In other words, an encompassing, generic uncontested national history politics, that enforces a benevolent interpretation of the great events and memories of the national past, is seen as the necessary antidote to possibly dangerous, confrontational interpretations of history.

These two divides together strengthen and enforce each other. Their interaction makes resistance to the dominant mnemonic regime more difficult and endows the regime with a degree of hegemony. A good example of this comes through in the documentation of the Finland 100 celebrations I have discussed in this article. The highlighting of troubled aspects of the past, such as the exclusion of minorities and discriminatory or even racist behavior, is shunned for fear of undermining progressivist and inclusive politics in the present. In other words, if new historical information about past atrocities and questionable processes and trajectories of nation-making or national unity were allowed to be promulgated openly and democratically in the public sphere, not to mention with state support, this might lead to confrontations and setbacks in the slow development of a supposedly progressive, yet more extensive and, ideally, all-encompassing national culture in the present and future.

In a very simplified sense, all this is analogous to a museum where national history is on display. The audience is encouraged to come and see the exhibit, but only the curators get to touch the objects and decide what will be displayed, and how and with what explanations. Even the researchers who discovered the objects on display do not have a say in how they are presented once they are exposed to the public's eyes. In other words, the state's history politics aims to prevent other perspectives from undermining the foregrounding of a particular and historically simplified narrative of national continuity and progress. The difference between Finland 100 and previous similar efforts is that outside consultants, public relations managers, and new technologies of communication provided an inescapable exhibition of national history that reached into more spheres of life. In the words of the lone historian who participated in the official self-evaluation, Finland 100 presented "new and fresh forms of expression" for

${ }^{90}$ Kettunen, "Kansallinen 'me' ja historia globaalistuvassa maailmassa," 1-8. 
"just the same old story." 91 The politics of history in Finland centers on the extension of the dominant narrative into the future. As such, despite a more immersive museum experience, this mnemonic regime promotes the historical traditions and the politics of an invented national narrative from the early twentieth century, rather than welcoming the arrival of twenty-first century democratic history politics.

${ }^{91}$ VNK, Suomi 100 vuotta. Yhdessä. Suomi 100 -juhlavuoden raportti, 106. 